\title{
Evolved gas analysis (TG-DSC-FTIR) and (Pyr-GC-MS) in the disposal of medicines (aceclofenac)
}

\author{
Maristela Denck Colman ${ }^{a}$, Simone Rosa da Silveira Lazzarotto ${ }^{a}$, Marcelo Lazzarotto ${ }^{\text {, }}$, \\ Fabrício Augusto Hansel ${ }^{\mathrm{b}}$, Tiago André Denck Colman ${ }^{\mathrm{c}}$, Egon Schnitzler ${ }^{\mathrm{a}, *}$ \\ a State University of Ponta Grossa, Av. Carlos Cavalcanti, 4748, ZIP 84.030-900, Ponta Grossa, Paraná, Brazil

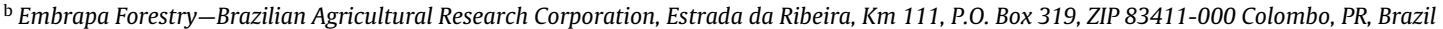 \\ ' São Paulo State University “Julio de Mesquita Filho”, Chemistry Institute of Araraquara, Araraquara, SP, Brazil
}

\section{A R T I C L E I N F O}

\section{Article history:}

Received 16 November 2015

Received in revised form 3 March 2016

Accepted 5 March 2016

Available online 9 March 2016

\section{Keywords:}

Pyrolysis

Aceclofenac

Thermal analysis

TG-DSC-FTIR

Pyr-GC-MS

\begin{abstract}
A B S T R A C T
During the twentieth century the growth of industrialisation, urbanisation and populations culminated in huge areas of waste disposal worldwide. Consequently, the management of the disposal of medicines (expired or not) is important in order to minimise the possibility of environmental pollution. A sample of aceclofenac (purity $=99.77 \%$ and m.p. $=151.63^{\circ} \mathrm{C}$ ) was analysed by TG-DSC-FTIR in nitrogen atmosphere . The TG-DSC curves showed two main stages of decomposition, with loss of organic matter generating carbonaceous derivatives as final residue. The use of coupled FTIR suggested the loss of $\mathrm{CO}, \mathrm{CO}_{2}$ and/or 2-chloro-propanoic acid/2-chloro-butanoic acid. The use of fast pyrolysis (Pyr) coupled with GC-MS suggested that the main compounds that were released were 1-(2,6-dichlorophenyl)-2-indolinone and 2,6-dichloro- $N$-(2-methylphenyl)-benzenamine. The differences in the results between the techniques were due to the experimental conditions used for each instrument.
\end{abstract}

(c) 2016 Elsevier B.V. All rights reserved.

\section{Introduction}

Thermal analysis techniques are widely used in studies of pharmaceutical compounds (active ingredients) as well as their excipients. These techniques are employed to check the thermal decomposition and thermal stability [1-7], polymorphism and pseudo-polymorphism [8-10], purity and melting point determination $[11,12]$, interactions with excipients, and other properties of interest in the pharmaceutical industry [13-15].

Aceclofenac, whose chemical name is 2-[2-[2-[(2,6dichlorophenyl)amino]phenyl]acetoxyacetic] acid is a white crystalline powder which is insoluble in water. It is a non-steroidal anti-inflammatory drug (NSAID) that is used mainly in the treatment of some rheumatic diseases It has better gastric tolerance than other drugs from the same group. In chemical terms, aceclofenac is derived from arylacetic acid; it is a non-selective cyclo-oxygenase (COX) reducing metabolites that provide antiinflammatory and anti-arthritic effects, analgesic and antipyretic.

\footnotetext{
* Corresponding author.

E-mail address: egons@uepg.br (E. Schnitzler).
}

It is prescribed mainly for diseases such as rheumatoid arthritis, ankylosing spondylitis and osteoarthritis [16-19].

Pharmaceutical drugs are chemical substances which are intended for use in the diagnosis, treatment, cure or prevention of diseases in humans and animals. There are several studies in the literature reporting many aspects of the pharmacological action of aceclofenac [20-22] but they are few studies regarding the thermal and structural characteristics of this drug, as well as the proper method of disposal after it has expired.

Population growth and consequent industrialisation cause problems related to waste disposal $[23,24]$. The present study was conducted in order to assess the thermal behaviour of aceclofenac. The main objective was to characterise aceclofenac using the following instrumental techniques: thermogravimetric analysis, differential scanning calorimetry and Fourier transform infrared spectroscopy (TG-DSC-FTIR), as well as coupled fast pyrolysis gas chromatography mass spectrometry (Pyr-GC-MS).

\section{Materials and methods}

The sample used in this investigation was aceclofenac, which was of pharmaceutical grade and which was acquired in the city of Ponta Grossa, Paraná, Brazil, lot n. 11020326A. 

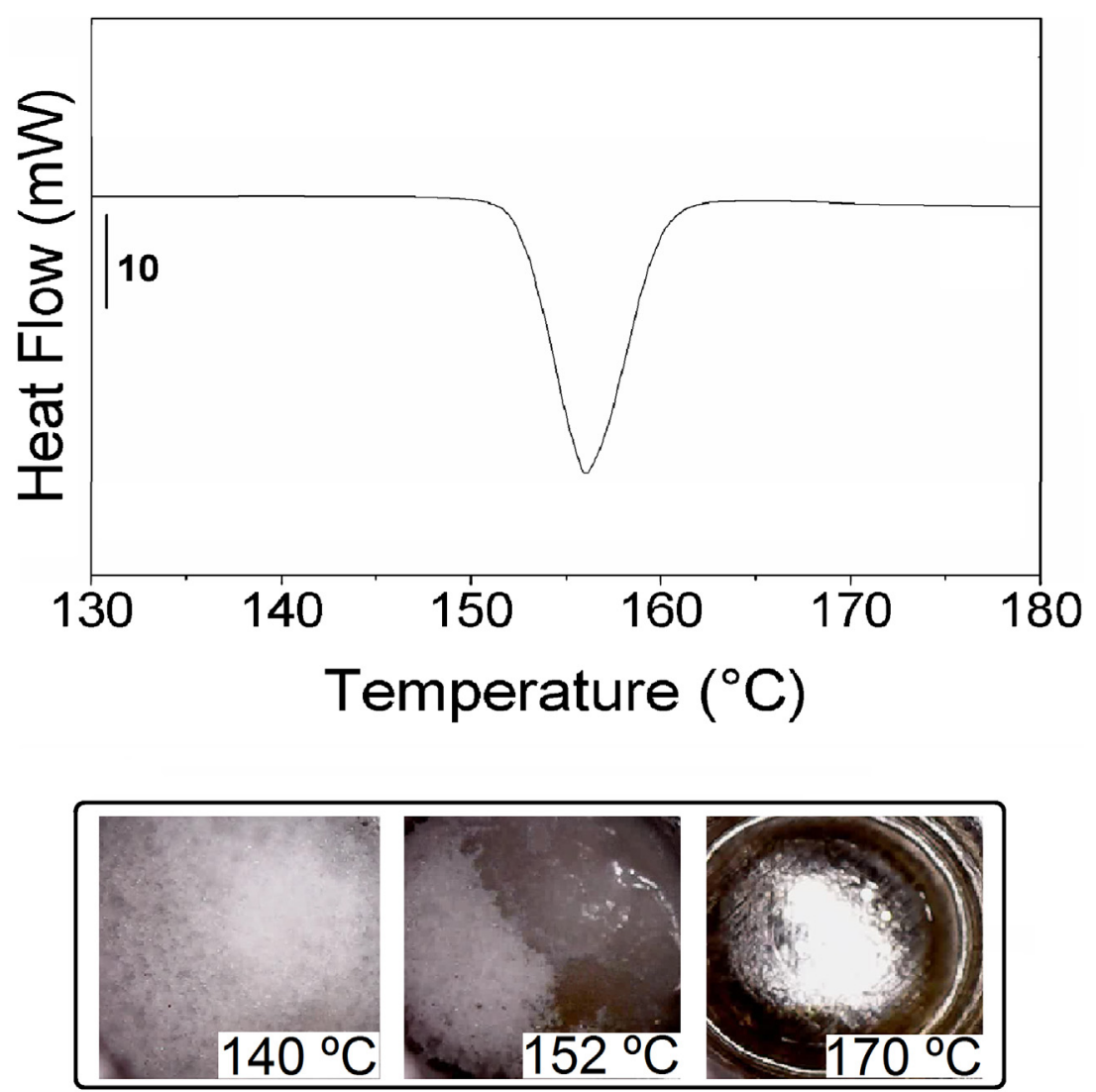

Fig. 1. DSC curve and images of thermomicroscopy.

\subsection{Differential scanning calorimetry (DSC)}

The DSC curves were obtained in a DSC-Q200 calorimeter (TA Instr. Co., USA), which was calibrated according to the manufacturer's recommendation: standard indium 99.99\% purity, m.p. $156.6^{\circ} \mathrm{C}$ and $\Delta \mathrm{H} 28.56 \mathrm{Jg}^{-1}$. A mass sample was around $2 \mathrm{mg}$ and the sample was heated from $130^{\circ} \mathrm{C}$ to $180^{\circ} \mathrm{C}$ using an aluminium crucible with perforated lid with $1.0 \mathrm{~mm}$ orifice, under $\mathrm{N}_{2}$ atmosphere, with a flow rate of $50 \mathrm{mLmin}^{-1}$ and a heating rate of $1{ }^{\circ} \mathrm{C} \mathrm{min}^{-1}$. Universal Analysis software was used to determine the purity of the sample.

\subsection{Thermomicroscopy}

The images were obtained by digital microscope coupled upon DSC cell. The microscope is equipped with color CMOS sensor and lens glass, $2 \mathrm{M}$ pixel resolution with increased $800 \times$. The software AMCAP V9.016 was used for capturing images.

\subsection{Evolved gas analysis (EGA)}

EGA was performed using the simultaneous techniques of TGDSC-FTIR (slow pyrolysis in nitrogen atmosphere) and PyrolysisGC-MS (fast pyrolysis in static atmosphere).

\subsection{Thermogravimetric analysis, differential scanning calorimetry and fourier transform infrared spectroscopy (TG-DSC-FTIR)}

The TG-DSC curves were obtained using a TGA 1 thermal analysis system (Mettler, Switzerland). A quantity of $10 \mathrm{mg}$ of sample was used in an open $\alpha$-alumina crucible in $\mathrm{N}_{2}$ atmosphere with

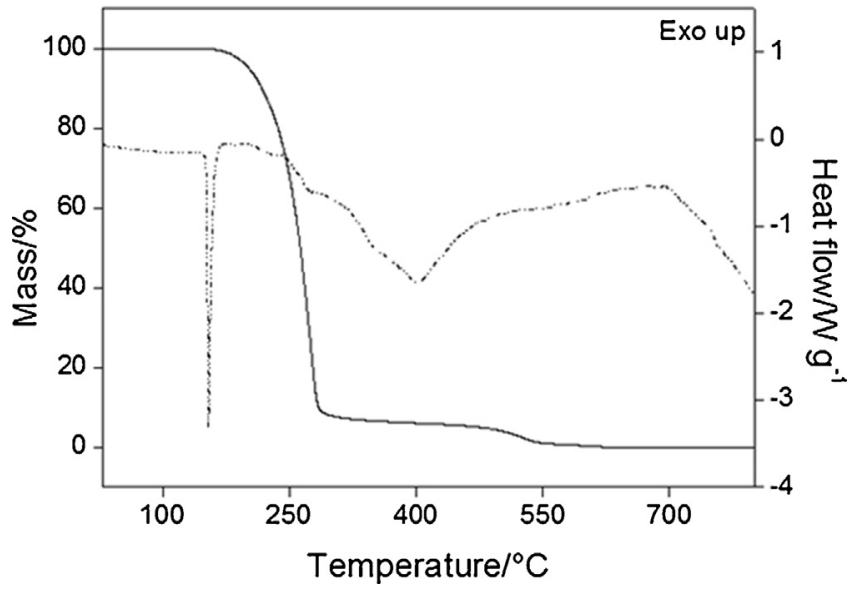

Fig. 2. TG-DSC curves of aceclofenac.

a flow rate of $50 \mathrm{~mL} \mathrm{~min}^{-1}$. The samples were heated from $30^{\circ} \mathrm{C}$ to $850^{\circ} \mathrm{C}$ with a heating rate of $10^{\circ} \mathrm{C} \mathrm{min}^{-1}$. The equipment was preliminarily calibrated with standard weight and the calibration was checked with calcium oxalate monohydrate. Stare Evolution software was used to analyse the results. A Nicolet FTIR coupled spectrophotometer with gas cell and DTG S KBr detector was used. For the coupling, we used a stainless steel transfer line of $120 \mathrm{~cm}$ in length and $3 \mathrm{~mm}$ in diameter, which was heated to $225^{\circ} \mathrm{C}$. The gas cell was maintained at $250^{\circ} \mathrm{C}$ and the spectra were obtained with a resolution of $4 \mathrm{~cm}^{-1}$. Omnic software, fitted with spectra from 46 different libraries, was used for data analysis. 


\subsection{Pyrolysis-GC-MS}

Pyrolysis was carried out at $700^{\circ} \mathrm{C}$ for $10 \mathrm{~s}$ using a CDS 5000 pyropobe; the coil heater was set at $10^{\circ} \mathrm{C} \mathrm{ms}^{-1}(8.0 \mathrm{mg})$. The other conditions for the pyroprobe were: temperature interface programme: $-75^{\circ} \mathrm{C}$ to $290^{\circ} \mathrm{C}$ at $100^{\circ} \mathrm{C} \mathrm{min}^{-1}$ then held for $120 \mathrm{~s}$, oven $290^{\circ} \mathrm{C}$, and transfer line $290^{\circ} \mathrm{C}$. The pyrolysed compounds were analysed using a Focus GC gas chromatography in tandem with a Polaris Q ion trap mass spectrometer (Thermo), equipped with a BPX5 capillary column $(60 \mathrm{~m} \times 0.25 \mathrm{~mm}, 25 \mu \mathrm{m}$ film thickness). The compounds were introduced via the pyroprobe transfer line into a split/splitless injector (split $1: 50,290^{\circ} \mathrm{C}$ ). A GC oven was programmed from $40^{\circ} \mathrm{C}$ (held for $5 \mathrm{~min}$ ) to $300^{\circ} \mathrm{C}$ at $7^{\circ} \mathrm{C} \mathrm{min}^{-1}$ and held at $300^{\circ} \mathrm{C}$ for $5 \mathrm{~min}$. The carrier gas was helium, at a constant flow of $1.0 \mathrm{~mL} \mathrm{~min}^{-1}$. The GC-MS interface and ion source temperatures were $300^{\circ} \mathrm{C}$ and $200^{\circ} \mathrm{C}$, respectively. The ion trap mass spectrometer was operated in the positive impact electronic mode at $70 \mathrm{eV}$, scanning was in the range of $m / z 50-650$ in a 0.58 total scan time, and the emission current was $250 \mathrm{~mA}$.

\section{Results and discussion}

The DSC curve (Fig. 1) shows an endothermic event near to $152{ }^{\circ} \mathrm{C}$, this event was attributed to melting of aceclofenac, as can be seen in thermomicroscopy (Supplementary material). The melting point was used to calculate the purity of the aceclofenac, according to the Van't Hoff equation.

The DSC curve was performed according to the procedure described by American Society for Testing and Materials [28], and showed that aceclofenac had a purity of $99.77 \%$ and a melting point of $151.63^{\circ} \mathrm{C}$.

The TG-DSC curve (Fig. 2) showed the decomposition of aceclofenac in two main stages of weight loss between $160-280^{\circ} \mathrm{C}$ and $280-550{ }^{\circ} \mathrm{C}$, with losses of $93.20 \%$ and $6.70 \%$, respectively. The thermal decomposition residue was $0.1 \%$ of the initial mass.

Two endothermic events were observed in the DSC curve. The first peak was at $159^{\circ} \mathrm{C}$ and was attributed to the melting of theaceclofenac; the second peak was at at $401{ }^{\circ} \mathrm{C}$ and was asso-
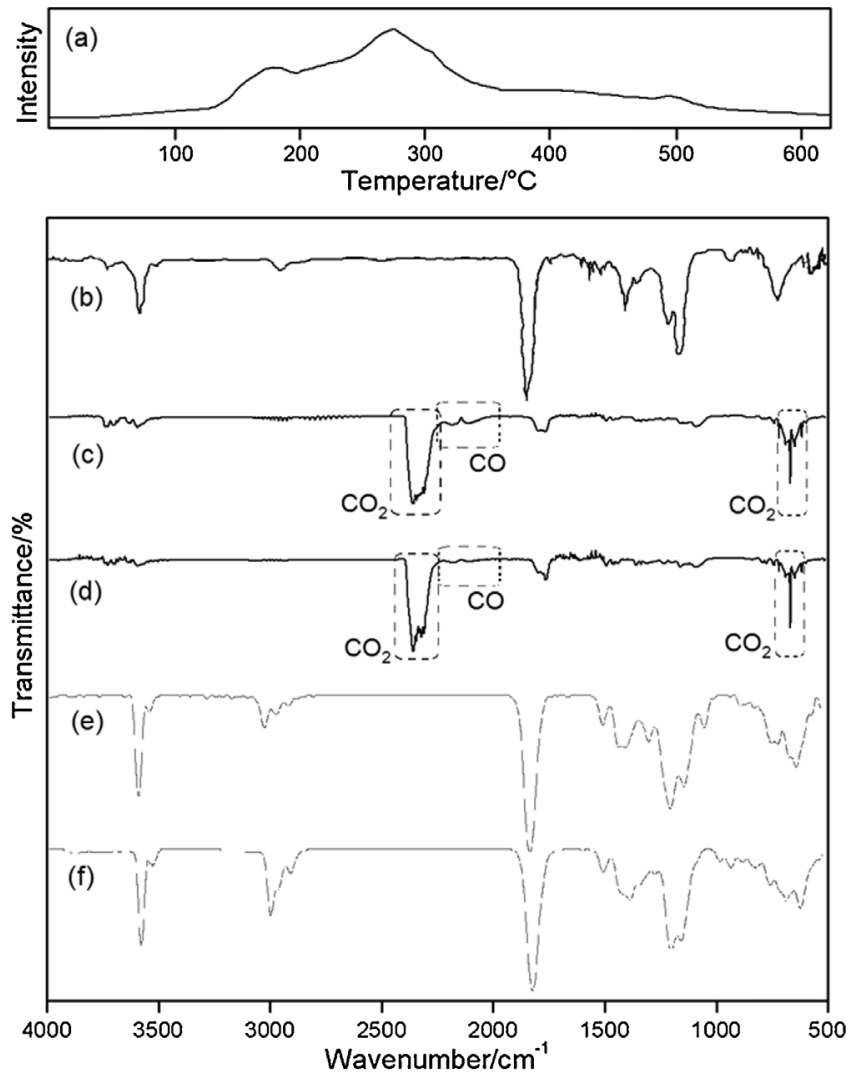

Fig. 3. EGA for FTIR of aceclofenac.

ciated with the two steps of weight loss attributed to the pyrolysis of the compound.

The FTIR spectra of the released gases are shown in Fig. 2. Comparison of the spectra obtained from libraries present in the FTIR software $[25,26]$ suggests that the decomposition of the drug released $\mathrm{CO}, \mathrm{CO} 2$, 2-chloro-propanoic acid (C3H5ClCO2) and/or 2chloro-butanoic acid (C4H7ClO2), Fig. 3.

Table 1

Relative abundance and molecular loss of pyrolysis-derived compounds of aceclofenac.

\begin{tabular}{|c|c|c|c|c|c|}
\hline ID & Compounds & $\mathrm{RRT}^{\mathrm{b}}$ & $\mathrm{MM}^{\mathrm{c}}$ & $\mathrm{ML}^{\mathrm{d}}$ & $\%$ \\
\hline 1 & toluene & 3.35 & 92 & $\mathrm{C}_{9} \mathrm{H}_{5} \mathrm{Cl}_{2} \mathrm{NO}_{4}$ & 0.06 \\
\hline 2 & benzoxazole & 2.26 & 119 & $\mathrm{C}_{9} \mathrm{H}_{8} \mathrm{Cl}_{2} \mathrm{O}_{3}$ & 0.05 \\
\hline 3 & 1,3-dichlorobenzene & 2.10 & 146 & $\mathrm{C}_{10} \mathrm{H}_{9} \mathrm{NO}_{4}$ & 0.10 \\
\hline 4 & 2,4-dichlorotoluene & 1.82 & 160 & $\mathrm{C}_{9} \mathrm{H}_{7} \mathrm{NO}_{4}$ & 0.11 \\
\hline 5 & 2,6-dichloroaniline & 1.62 & 161 & $\mathrm{C}_{10} \mathrm{H}_{8} \mathrm{O}_{4}$ & 0.04 \\
\hline 6 & 2,6-dichlorophenyl isocyanate & 1.55 & 187 & $\mathrm{C}_{9} \mathrm{H}_{10} \mathrm{O}_{3}$ & 0.04 \\
\hline 7 & acridine & 1.14 & 179 & $\mathrm{C}_{3} \mathrm{H}_{4} \mathrm{Cl}_{2} \mathrm{O}_{4}$ & 0.06 \\
\hline 8 & 2,6-dichloro- $N$-phenylaniline & 1.13 & 237 & $\mathrm{C}_{4} \mathrm{H}_{4} \mathrm{O}_{4}$ & 0.05 \\
\hline 9 & 2,6-dichloro- $\mathrm{N}$-(2-methylphenyl)-benzenamine & 1.11 & 251 & $\mathrm{C}_{3} \mathrm{H}_{2} \mathrm{O}_{4}$ & 1.21 \\
\hline 10 & o 2,6-dichloro- $N$-2-ethanal-phenylaniline & 1.06 & 279 & $\mathrm{C}_{2} \mathrm{H}_{2} \mathrm{O}_{3}$ & 0.05 \\
\hline 11 & $\underset{\mathrm{C}}{\text { chloroacridine }^{\mathrm{a}}}$ & 1.06 & 213 & $\mathrm{C}_{3} \mathrm{H}_{5} \mathrm{ClO}_{4}$ & 0.28 \\
\hline 12 & o 2-chloro- $N$-2-acetoxy-phenylaniline & 1.03 & 261 & $\mathrm{C}_{2} \mathrm{H}_{2} \mathrm{ClO}_{2}$ & 0.21 \\
\hline 13 & 4-chloroacridine & 1.03 & 213 & $\mathrm{C}_{3} \mathrm{H}_{5} \mathrm{ClO}_{4}$ & 1.02 \\
\hline 14 & 1-(2,6-dichlorophenyl)-2-indolinone & 1.00 & 277 & $\mathrm{C}_{2} \mathrm{H}_{4} \mathrm{O}_{3}$ & 94.91 \\
\hline
\end{tabular}

a 4-Chloroacridine isomer-the position of chloride substitute was not identified.

b Relative retention time against the major pyrolysis-derived compound, 14 .

c Molecular mass.

d Molecular loss.

e Integrated TIC areas were normalized and an individual compounds was expressed as a relative amount of total (\%). 
<smiles>O=C(O)COC(=O)Cc1ccccc1Nc1c(Cl)cccc1Cl</smiles><smiles>C1=CC1</smiles><smiles>O=C(O)CO</smiles><smiles>O=C(O)COC(=O)Cc1ccccc1Nc1c(Cl)cccc1Cl</smiles><smiles>CC(=O)OCC(=O)O</smiles>

Fig. 4. Thermal decomposition mechanism suggested for aceclofenac.

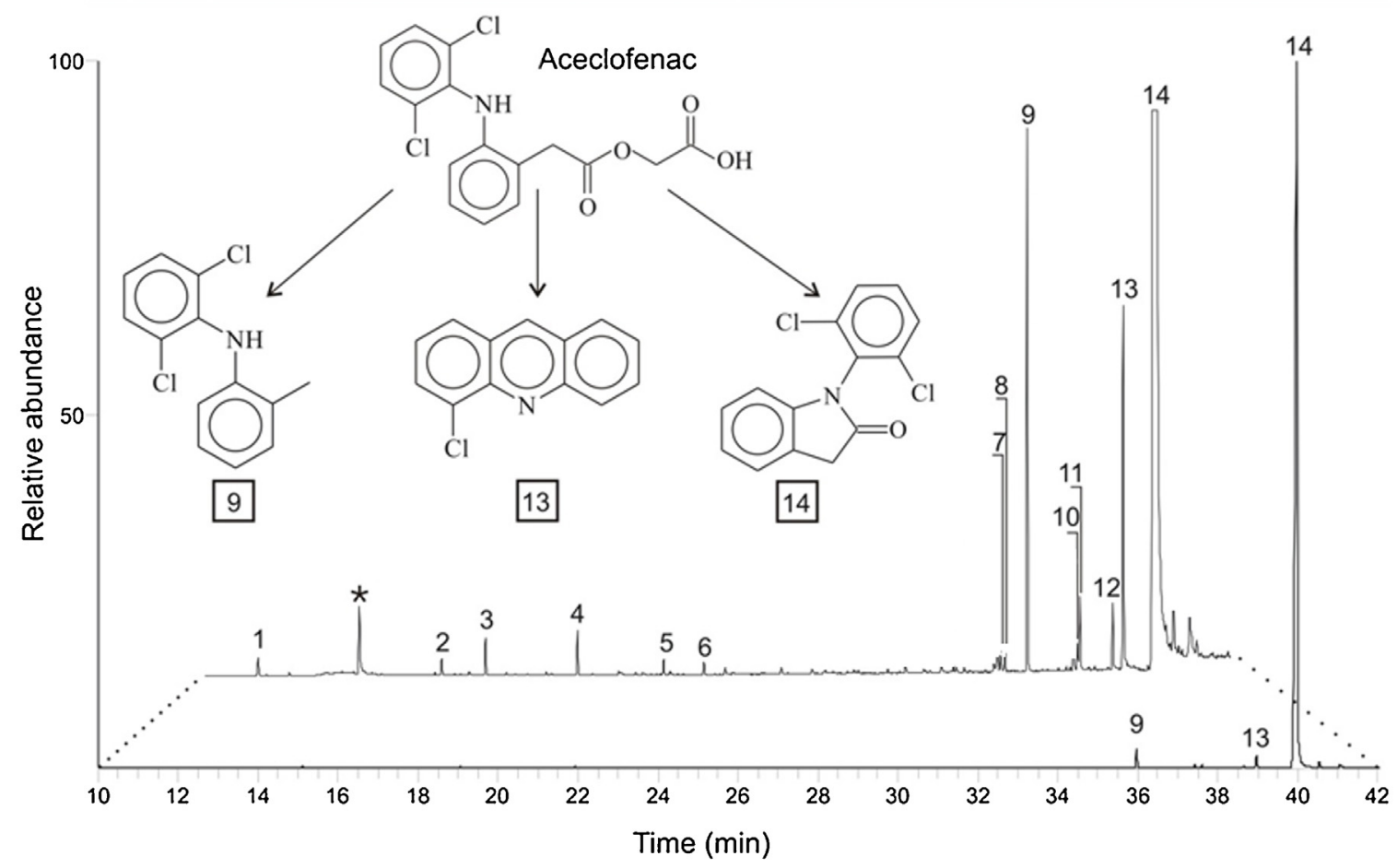

Fig. 5. EGA for Pyr-GC-MS of aceclofenac.

The Pyr-GC-MS analysis at $700^{\circ} \mathrm{C}$ showed 14 compounds, which were identified by their mass spectra (Table 1$)$. The main pyrolysis-derived compound was 1-(2,6-dichlorophenyl)-2indolinone, which accounted for $94.91 \%$ of the total compounds (Fig. 4).

Other compounds detected are: 2,6-dichloro- $\mathrm{N}-(2-$ methylphenyl)-benzenamine and 4-chloroacridine, albeit in much lower amounts (1\%). The other 11 components were observed in trace amounts $(<1 \%)$ of the total detected compounds (Table 1).

The major component was formed due to the cleavage of the ester bond and the migration of hydrogen from the secondary amine to form a cyclic amide. The hydroxyacetic acid $\left(\mathrm{C}_{2} \mathrm{H}_{4} \mathrm{O}_{3}\right)$ leaving group was not detected in the Py-GC-MS analysis (Fig. 5). It is well known that organic acid groups are not easily detected by pyrolysis [27], thus decarboxylation of the leaving group was to be expected, given the presence of undetectable compounds. Of the three major compounds, only the 4-chloroacridine provided a chloride-substitution leaving group $\left(\mathrm{C}_{3} \mathrm{H}_{5} \mathrm{ClO}_{4}\right)$, which was interpreted as 2-chloroformic ester acetic acid. As mentioned above in relation to hydroxyacetic acid, this chloride leaving group was not detected in the analysis.

The thermal decomposition mechanism of the two main compounds is suggested (Fig. 4):

The discrepancies between the results of TG-DSC-FTIR and PyrGC-MS were attributed to differences between the parameters of the pyrolysis of aceclofenac.

\section{Conclusion}

The thermomicroscopy allows the melting attribution of compound and the DSC technique was important in determining the 
purity of the active ingredient, and when coupled with the other instruments it provided important information about these compounds.

The TG-DSC techniques were used to determine the thermal decomposition of the compound, which occurred in two consecutive stages of mass loss. The DSC analysis made it possible to verify the endothermic events, which were attributed to the melting and the pyrolysis of the compound.

The EGA by TG-DSC-FTIR suggested that the gases released during decomposition were possibly $\mathrm{CO}, \mathrm{CO}_{2}$, 2-chloro-propanoic acid $\left(\mathrm{C}_{3} \mathrm{H}_{5} \mathrm{ClCO}_{2}\right)$ and/or 2-chloro-butanoic acid $\left(\mathrm{C}_{4} \mathrm{H}_{7} \mathrm{ClO}_{2}\right)$.

The EGA by Pyr-GC-MS suggested that the gases released during decomposition were possibly 1 -(2,6-dichlorophenyl)-2-indolinone (94.91\%) and 2,6-dichloro- $N$-(2-methylphenyl)-benzenamine (1.21\%).

The EGA analysis allowed the observation that the pyrolysis releases aceclofenac chlorinated compounds into the atmosphere, thus the process of disposing of this drug should be better planned to avoid contamination of the environment.

\section{Acknowledgments}

The authors would like to express their thanks for financial support from CNPq (Brazil) and also to Prof. Dr. Massao Ionashiro-LATIG (Ivo Giolito Laboratory of Thermal Analysis) for the TG-DSC and FTIR analyses.

\section{Appendix A. Supplementary data}

Supplementary data associated with this article can be found, in the online version, at http://dx.doi.org/10.1016/j.jaap.2016.03.005.

\section{References}

[1] E. Schnitzler, M. Kobelnik, G.F.C. Sotelo, G. Bannach, M. Ionashiro, Thermoanalytical study of purine derivative compounds, Ecl. Quím. 29 (2004) $71-78$.

[2] G. Bannach, P. Cervini, E.T.G. Cavalheiro, M. Ionashiro, Using thermal and spectroscopic data to investigate the thermal bahavior of epinephrine, Thermochim. Acta 499 (2010) 123-127.

[3] R. Maxwell, J. Chickos, Na examination of the thermodynamics of fusion, vaporization and sublimation of ibuprofen and naproxen by correlation gas chromatography, J. Pharm. Sci. 101 (2012) 805-814.

[4] B. Titta, G. Bandur, D. Titta, Novel Cu(II) complex with non-steroidal anti-inflamatory drugs. Synthesis, characterization and thermal investigation of the complex with ibuprofen, Rev. Chim. 64 (2013) 569-573.

[5] G. Vlase, T. Vlase, N. Doca, Thermal behavior of some phenitoine pharmaceuticals, J. Therm. Anal. Calorim. 92 (2008) 259-262.

[6] G. Bannach, R. Arcaro, D.C. Ferroni, A.B. Siqueira, O. Treu-Filho, M. Ionashiro, E. Schnitzler, Thermoanalytical study of some anti-inflammatory analgesic agents, J. Therm. Anal. Calorim. 102 (2010) 163-170.
[7] D.A. Gálico, R.B. Guerra, G.L. Perpétuo, L.S. Santos, E. Schnitzler, G. Bannach, Thermal and spectroscopic studies on solid ketoprofen of lighter trivalent lanthanides, Braz. J. Therm. Anal. 1 (2012) 42-47.

[8] D. Giron, Thermal analysis and calorimetric methods in the characterization of polymorphs and solvates, Thermochim. Acta 248 (1995) 1-59.

[9] B. Perrenot, G. Widmann, Polymorphism by differential scanning calorimetry, Thermochim. Acta 234 (1994) 31-39.

[10] D. Giron, Investigations of polymorphism and pseudo-polymorphism in pharmaceuticals by combined thermoanalytical techniques, J. Therm. Anal. Calorim. 64 (2001) 37-60.

[11] D. Giron, S. Monnier, M. Mutz, P. Peichon, T. Buser, F. Stowasser, K. Shulze, M. Bellus, Comparisson of quantitative methods for analysis of polyphasic pharmaceuticals, J. Therm. Anal. Calorim. 89 (2007) 729-743.

[12] F. Giordano, A. Rossi, I. Pasquali, R. Bettini, E. Frigo, A. Gazzaniga, M.E. Sangalli, V. Mileo, S. Catinella, Thermal degradation and melting point determination of diclofenac, J. Therm. Anal. Calorim. 73 (2003) 509-518.

[13] Z. Aigner, R. Heinrich, E. Sipos, G. Farkas, A. Ciurba, O. Berkesi, P. Szabó-Révész, Compatibility studies of aceclofenac with retard tablet excipients by means of thermal and FT-IR spectroscopic methods, J. Thermal. Anal. Calorim. 104 (2011) 265-271.

[14] M.D. Colman, C.S. Oliveira, T.A.D. Colman, E. Schnitzler, Avaliação termoanalítica e estrutural de misturas binárias aceclofenaco/amido de pinhão, Braz. J. Therm. Anal. 4 (2015) 44-47.

[15] S. Vecchio, A. Catalani, V. Rossi, M. Tomassetti, Thermal analysis on vaporization of some analgesics. Acetanilide derivatives, Thermochim. Acta 420 (2004) 99-104.

[16] R. Yamazaki, S. Kawai, T. Matsuzaki, N. Kaneda, S. Hashimoto, T. Yokokura, R. Okamoto, T. Koshino, Y. Mizushima, Aceclofenac blocks prostaglandin E production following its intracellular conversion into cyclooxygenase inhibitors, Eur. J. Pharmacol. 329 (1997) 181-187.

[17] H.P. Rang, M.M. Dale, J.M. Ritter, P. Gardner, Farmacologia, 7th ed., Elsevier, 2012.

[18] C.M. Setty, D.V.K. Prasad, V.R.M. Gupta, B. Sa, Development of fast dispersible aceclofenac tablets: effect of functionality of superdisintegrants, Indian J. Pharm. Sci. 70 (2008) 180-185.

[19] F. Shakeel, S. Baboota, A. Ahuja, J. Ali, M. Aqil, S. Shafiq, Nanoemulsions as vehicles for transdermal delivery of aceclofenac, AAPS Pharm. Sci. Technol. 8 (2007) E1-E9.

[20] S. Ghosh, B.B. Barik, A comparative study of the pharmacokinetics of conventional and sustained-release tablet formulations of aceclofenac in healthy male subjects, Trop. J. Pharm. Res. 9 (2010) 395-399.

[21] I.S. Chandiran, T. Sivakumar, B.P. Kumar, Preparation and evaluation of aceclofenac loaded biodegradable microspheres, Int. J. Pharm. Biomed. Res. 1 (2010) 19-23.

[22] M. Sevukarajan, S.S. Parveen, R. Nair, T.Md. Baldivaddin, Preparation and characterization of aceclofenac salt by using triethanolamine, J. Pharm. Sci. Res. 3 (2011) 1280-1283.

[23] A.N.E. Rahman, M.A.K. Akmal, K.B.S. Prasad, Pyrolysis of solid wastes, J. Sci. Ind. Res. 60 (2001) 52-59.

[24] P. Eickhoff, I. Heineck, L.J. Seixas, Gerenciamento e distribuição final de medicamentos: uma discussão sobre o problema, Rev. Bras. Farm. 90 (2009) 64-68.

[25] EPA Vapor Phase, FTIR spectra library by software OMNIC 8.0.342 (Thermo Scientific) (2015).

[26] Nicolet TGA Vapor Phase, FTIR spectra library by software OMNIC 8.0.342 (Thermo Scientific) (2015)

[27] J. Kaal, A. Martinez-Cortizas, K.G.J. Nierop, P. Buurman, A detailed pyrolysis-GC-MS analysis of a black carbon-rich acidic colluvial soil (Atlantic ranker) from NW Spain, Appl. Geochem. 23 (2008) 2395-2405.

[28] E 928, Mole Percent Impurity by Differential Scanning Calorimetry, American Society for Testing and Materials, West Conshohocken, PA, 2016. 